\title{
Biochemical characterization of Pochonia chlamydosporia Q30 as biocontrol agent and plant growth promoter
}

\section{Caracterización bioquímica de Pochonia chlamydosporia Q30 como agente de biocontrol y promotor del crecimiento vegetal}

\author{
PACHECO-AGUILAR, Juan-Ramiro†*, JUÁREZ-CAMPUSANO, Yara-Suhan, CHÁVARO-ORTÍZ, \\ María del Socorro and BÁRCENAS-OROZCO, Evelyn-Crystel
}

Universidad Autónoma de Querétaro / Facultad de Química, Cerro de las campanas s/n, col. Las Campanas, C.P. 76040. Santiago de Querétaro Qro.

ID $1^{\text {st }}$ Author: Pacheco-Aguilar, Juan-Ramiro / ORC ID: 0000-0001-8365-4488, CVU CONACYT ID: 87499

ID $1^{\text {st }}$ Coauthor: Yara Suhan, Juárez-Campusano / ORC ID: 0000-0003-0886-5466, CVU CONACYT ID: 710264

ID $2^{\text {nd }}$ Coauthor: María Del Socorro, Chávaro-Ortíz / ORC ID: 0000-0013-7516-1675, CVU CONACYT ID: 289699

ID $3^{\text {rd }}$ Coauthor: Evelyn-Crystel, Barcenas-Orozco / ORC ID: 0000-0002-3032-9072,

DOI: $10.35429 / J E S N .2020 .17 .6 .17 .21$

Received April 26, 2020; Accepted June 30, 2020

\begin{abstract}
Pochonia chlamydosporia is a natural soil fungi, which in recent years has gained importance for its ability to nematodes biocontrol and its beneficial plant interaction. The biochemical characterization of new isolates is important to determine their potential as biocontrol agent and plant growth promoter. In the present work, through the use of specific culture media, it was found that Pochonia chlamydosporia Q30 possesses chitinolytic activity, which could involve in the degradation of the egg wall and the cuticule of the juvenile nematode stages, amilolytic and pectinolytic activiy related to root colonization as endophyte was also found. Finally, phosphate solubilization $(242.6 \pm$ $27.1 \mathrm{mg} / \mathrm{L})$ and indoleacetic acid production $(10.0 \pm 1.2$ $\mathrm{mg} / \mathrm{L}$ ) were detected as plant gowth promoting properties, which were later verified in watermelon seedlings, whose inoculation with $10^{5}$ chlamydospores, increased the height and the stem diameter in a 13 and $6 \%$, respectively. In conclusion, $P$. chlamydosporia $\mathrm{Q} 30$ has potential to be tested as biocontrol agent for nematodes and plant growth promoter.
\end{abstract}

Indoleacetic acid, Nematodes, Endophyte

\begin{abstract}
Resumen
Pochonia chlamydosporia es un hongo natural del suelo, que en años recientes años ha cobrado importancia por su capacidad en el biocontrol de nematodos y su interacción benéfica con las plantas. La caracterización bioquímica de nuevos aislados es fundamental para determinar su potencial como agente de biocontrol y como promotor del crecimiento de plantas. En el presente trabajo, mediante el empleo de medios de cultivos específicos, se encontró que Pochonia chlamydosporia Q30 posee actividad quitinolítica, la cual podría estar involucrada en la degradación de la pared de los huevos y la cutícula de las fases juveniles de los nematodos, también se registraron actividades amilolítica y pectinolítica, relacionadas con la colonización de la raíz como endófito. Finalmente, se detectó la solubilización de fosfatos (242.6 \pm $27.1 \mathrm{mg} / \mathrm{L})$ y la producción de acído indolácetico $(10.0 \pm 1.2$ $\mathrm{mg} / \mathrm{L})$ como propiedades promotoras del crecimiento vegetal, lo cual posteriormente fue comprobado en plántulas de sandía, cuya inoculación con $10^{5}$ clamidiosporas, incremento la altura y el diámetro del tallo en un 13 y $6 \%$, respectivamente. En conclusión, $P$. chlamydosporia Q30 posee potencial para ser ensayado como agente de biocontrol de nematodos y como promotor de crecimiento vegetal.
\end{abstract}

Ácido indolacético, Nematodos, Endófito

Citation: PACHECO-AGUILAR, Juan-Ramiro, JUÁREZ-CAMPUSANO, Yara-Suhan, CHÁVARO-ORTÍZ, María del Socorro and BÁRCENAS-OROZCO, Evelyn-Crystel. Biochemical characterization of Pochonia chlamydosporia Q30 as biocontrol agent and plant growth promoter. Journal of Environmental Sciences and Natural Resources. 2020, 6-17: 17-21

\footnotetext{
* Correspondence to Author (email: juanramiro29@yahoo.com.mx)

$\dagger$ Researcher contributing first author.
} 


\section{Introduction}

Once the germination of the seeds in the soil begins, the root is quickly colonized by microorganisms, attracted by the exudate radicals, from here begin the plantmicroorganism relationships that have been studied in recent decades, these relationships can be neutral, beneficial or pathogenic (Nelson et al., 2018).

Among the beneficial relationships are those where the microorganisms protect the plant against parasitism and infections produced by bacteria, fungi and nematodes, the latter penetrate the roots, using them as niches where they complete their development and sexual cycle, producing tumors and gills, which affect the development of the host plant. Nematodes are non-segmented worms that are part of the soil microfauna and, that come to affect crops of agricultural importance such as chili, cucumber, tomato and eggplant among others (Carrillo et. al., 2000).

Among the antagonistic agents, it has been identified Pochonia chlamydosporia, which is a natural soil fungus that has shown biocontrol effect against nematodes of the genus Globodera, Heterodera, Meloidogyne, Nacobbus and Rotylenchulus. This fungus penetrates the roots of the plants in order to parasitize the eggs of the nematodes (Manzanilla et al., 2013).

However, the ability of $P$. chlamydosporia to promote host plant growth has also been reported, making it a versatile biocontrol agent (Dallemole et al., 2015). Biochemical characterization of new isolates of this species is necessary to exploit its full agronomic potential. In the present trial, the Pochonia chlamydosporia Q30 strain provided with SINQUIMICA SA de CV was characterized through biochemical tests in order to determine the presence of activities related to biological control and plant growth promotion.

\section{Methodology to be developed}

\section{Phosphate solubilization}

In order to determine the capacity to solubilize insoluble calcium phosphates, the liquid medium of Pikovskaya containing insoluble tricalcium phosphate was used as the only source of phosphorus (Nautiyal, 1999), in which active mycelium of the fungus was inoculated, being left to grow for 7 days at 25 ${ }^{\circ} \mathrm{C}$ with constant agitation at $150 \mathrm{rpm}$.

Then, the mycelium was filtered, and in the supernatant the soluble phosphorus was determined by spectrophotometry at $882 \mathrm{~mm}$ according to the molybdenum blue method (Ben et al., 2009).

\section{Production of indolacetic acid (AIA)}

The determination of AIA production was performed by growing $P$. chlamydosporia in Czapek Dox liquid medium with tryptophan (2 $\mathrm{mM}$ ) for 6 days at $25^{\circ} \mathrm{C}$ with constant agitation at $150 \mathrm{rpm}$. Then, cultures were centrifuged at $4000 \mathrm{rpm}$ for $20 \mathrm{~min}$ and, the supernatant was subjected to fractionated extractions with ethyl acetate to recover the AIA produced, the solvent was then recovered using a rotavapor, and the residue was resuspended in methanol, being then mixed with Salwoski's reagent to quantify the indolent compounds at $530 \mathrm{~nm}$ by spectrophotometry (Luna et al., 2013; Patel et al., 2018).

\section{Chitin degradation}

To determine chitinolytic activity, a disk of active mycelium of $P$. chlamydosporia was inoculated in triplicate into a modified liquid chitin medium containing $(\mathrm{g} / \mathrm{L})$ : colloidal chitin 2.0, $\left(\mathrm{NH}_{4}\right)_{2} \mathrm{SO}_{4} 1.0, \mathrm{~K}_{2} \mathrm{HPO}_{4} 0.1, \mathrm{MgSO}_{4} .7 \mathrm{H}_{2} \mathrm{O}$ 0.01 and, TSB 0.05. Cultures were kept at 25 ${ }^{\circ} \mathrm{C}$ for 7 days with constant agitation at 150 rpm. Mycelial growth of the fungus was considered positive for this activity (Halimahtussadiyah et al., 2017).

\section{Starch and pectin degradation}

Amylolytic and pectinolytic activities were tested by sowing a disk of active mycelium in the center of plates containing $1 \%$ starch agar and $1 \%$ pectin agar. 
Then, they were incubated for 7 days at $28{ }^{\circ} \mathrm{C}$. At the end, the plates were developed using a $0.5 \%$ lugol solution. Clarification of the area surrounding mycelial growth was considered positive for each of the activities (Guzmán et al., 2014).

\section{Chlamydospore production}

To obtain the spores that were used for the plant growth promotion trial, solid culture medium was prepared in $250 \mathrm{~mL}$ flasks, in which $20 \mathrm{~g}$ of washed, sifted $(1 \mathrm{~mm})$ and sterilized sand were placed, together with $20 \mathrm{~g}$ of sifted rice flour (mesh no. 70). The mixture was sterilized and cooled to room temperature, where $40 \mathrm{~mL}$ of sterile water and $10 \mathrm{~mL}$ of PDB medium where P. chlamydosporia had been previously grown for 7 days were added. Cultures were incubated at $18{ }^{\circ} \mathrm{C}$ for three weeks. At the end, $50 \mathrm{~mL}$ of a sterile $0.05 \%$ Tween solution were added to each flask to remove chlamydospores, the mixture was filtered through sieves with several openings to eliminate the substrates, and finally the chlamydospores were quantified in a microscope using a Neubauer camera (Silva et al., 2017).

\section{Plant growth promotion trials}

To evaluate the plant growth promoting effect of $P$. chlamydosporia, inoculation trials were carried out in watermelon seedlings, as a model plant. For this purpose, seeds were germinated in polystyrene trays that contained peat moss as substrate, after germination, plants were fertilized with a Steiner solution, and after 21 days, they were inoculated with a chlamydospore solution $\left(10^{5}\right.$ chlamydospores $/ \mathrm{mL}$ ). After 14 days, the seedlings were recovered to evaluate the effect of the inoculation on the height, diameter, stem and root weight. Five seedlings constituted an experimental unit with six replicates, as control plants were used without inoculation (Luna et al., 2013).

\section{Análisis Estadístico}

The results obtained from the plant growth promotion trial were subjected to analysis of variance and Tukey mean comparison test (0.05).

\section{Results \\ Biochemical properties related to the promotion of plant growth}

In the liquid medium Pikovskaya, P. chlamydosporia solubilized the insoluble tricalcium phosphate, producing average soluble phosphorus values of $242.56 \pm 27.16$ $\mathrm{mg} / \mathrm{L}$. These values are high compared to those reported by De Sauza et al. (2019), who tested this capacity in three field isolates, which produced values in the range of 36.6 to 47.5 $\mathrm{mg} / \mathrm{L}$. This property is related to the fungal production of organic acids such as acetic, citric and propionic acids. Soil applied inoculants with this property make phosphates more bioavailable to the plant, thus improving its development. As for the production of indolacetic acid (AIA), average values of $10.0 \pm 1.24$ $\mathrm{mg} / \mathrm{L}$ were recorded, which are low compared to those reported by Zavala et al. (2015), who found in nine environmental isolates, values in the range of $158-267 \mathrm{mg} / \mathrm{L}$. AIA is a phytohormone that is closely related to physiological processes such as induction of seed germination, root formation and plant growth.

\section{Biochemical properties related to root colonization and biological control}

$P$. chlamydosporia needs to penetrate the root tissues in order to gain access to and parasitize the nematodes. To do this, it first needs to produce pectinases and amylases that allow it to colonize the internal root tissues (Sunitha et al., 2013), Fig 1, shows the production of these enzymes by the Q30 strain. Afterwards, the production of chitinases is essential to carry out parasitism, since this enzyme carries out the degradation of the nematodes' eggshell and the integument of the juvenile stages (Olivares et al., 2002).

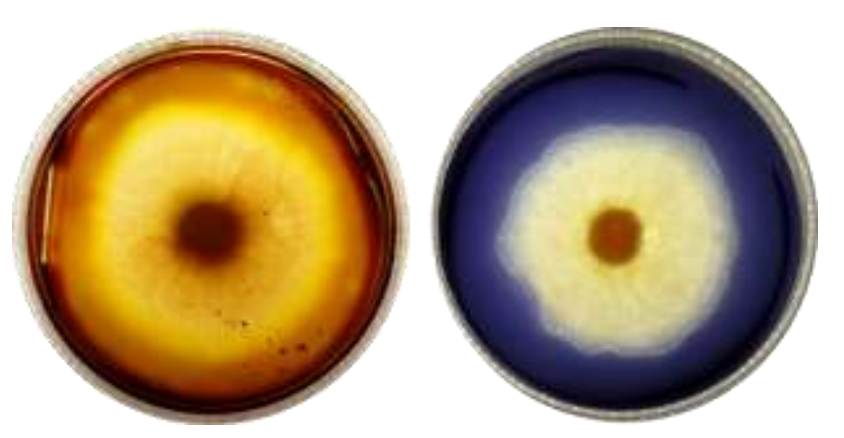

Figure 1 Pectinolytic and amylolytic activities (left and right, respectively), detected in Q30 
Chitinolytic activity was recorded by mycelial growth observed in liquid media, which contained mineral salts whose only source of carbon was colloidal chitin.

\section{Watermelon seedling growth promotion}

In the plant growth promotion trial, the inoculation of chlamydospores in watermelon seedlings had a significant effect on height and diameter, where an increase of $13 \%$ and $6 \%$, respectively, was registered (Table 1), although no differences were observed in the total biomass with respect to the control.

\begin{tabular}{|c|c|c|c|c|}
\hline Treatment & $\begin{array}{c}\text { Height } \\
\text { (cm) }\end{array}$ & $\begin{array}{l}\text { Diameter } \\
(\mathrm{mm})\end{array}$ & $\begin{array}{c}\text { Stem } \\
\text { weight } \\
\text { (g) }\end{array}$ & $\begin{array}{c}\text { Root } \\
\text { weight } \\
\text { (mg) }\end{array}$ \\
\hline Witness & $6.77 \mathrm{~A}$ & $4.28 \mathrm{~A}$ & $0.741 \mathrm{~A}$ & $75.33 \mathrm{~A}$ \\
\hline Q30 & $7.65 \mathrm{~B}$ & $4.52 \mathrm{~B}$ & $0.724 \mathrm{~A}$ & $62.28 \mathrm{~A}$ \\
\hline
\end{tabular}

Table 1 Effect of the inoculation of chlamydospores of $P$. chlamydosporia $\mathrm{Q} 30$ on the growth of watermelon seedlings. Equal letters in each column are not statistically different (Tukey, 0.05)

These increases could be due to the action of the AIA, which although in vitro low amounts of production were detected, could have an effect on the growth of seedlings. Dallemole et al. (2015) report that both mycelium and chlamydospore discs inoculation can be used as inoculants, since their application to tomato and lettuce sprouts significantly increased height and biomass. Zavala et al. (2015), report that P. chlamydosporia inoculation can also reduce tomato flowering and fruiting time, which may be due to AIA production and phosphate solubilization. This shows that P. chlamydosporia, is a versatile microorganism with great potential for use in agriculture.

\section{Acknowledgements}

The authors would like to thank the UAQ Linkage Fund for the financing granted to carry out the project, and the company SINQUIMCA SA de CV.

\section{Conclusions}

P. chlamydosporia Q30 produces AIA and solubilizes insoluble calcium phosphates, properties related to plant growth promotion.
Biochemical tests detected amylolytic, pectinolytic and chitinolytic enzyme activities in $P$. chlamydosporia $Q 30$, probably involved with root colonization and biocontrol effect towards nematodes.

P. chlamydosporia $Q 30$ could be used to improve the quality of watermelon seedling production, due to the effect it has as a plant growth promoter.

\section{References}

Ben, M. S. A., Elferjani, H. S., Haroun, F. A. \& Abdelnabi F. F. (2009) Determination of available nitrate, phosphate and sulfate in soil samples. International Journal of PharmTech Research, 1(3), 598-604.

Carrillo, F. J. A., García, E. R. S., Allende, M. R. \& Márquez. Z. I. (2000). Identificación y distribución del nematodo nodulador (Meloidogyne spp.) en hortalizas, en Sinaloa, México. Revista Mexicana de Fitopatología, 18(2), 115-119.

Dallemole, G. R., Grassi, D. F. L., Lopes, E. A., De Cassia, S. D. S. M., Meguni, K. M. C. \& Ferraz, S. (2015). Pochonia chlamydosporia promotes the growth of tomato and lettuce plants. Acta Scientiarum Agronomy, 37(4), 417-423.

De Sauza, G. A., Avelar, M. T. S., Vasconcelos, V. S., Leite, S. B., Grassi. D. F. L., De Oliveira, R. H. J. \& De Queiroz J. H. (2019). Understanding how Pochonia chlamydosporia increases phosphorus availability. Geomicrobiology Journal, 36(8), 747-751.

Guzmán, C. M., Zambrano, P. A., Rondón, D. E., Laurencio, S. J., Pérez, Q M., León A. M. \& Fernández, R R. (2014). Aislamiento, selección y caracterización de hongos celulolíticos a partir de muestras de suelo en Manabi-Ecuador. Revista de la Facultad de Ciencias Agrarias, 46(2), 177-189.

Halimahtussadiyah, R., Natsir, M., Kurniawati, D. \& Puspita, U. S. (2017). Isolation and identification of chitinolytic bacteria of pohara river of South East Sulawesi and the optimization production chitinase enzyme. AIP Conference Proceedings, 1823, 020062. 
Luna, M. L., Martínez, P. R. A., Hernández, I. M., Arvizu, M. S. M. \& Pacheco, A. J. R. (2013). Caracterización de rizobacterias aisladas de tomate y su efecto en el crecimiento de tomate y pimiento. Revista Fitotecnia Mexicana, 36(1), 63-69.

Manzanilla-López, R. H., Esteves, I., FinettiSialer, M. M., Hirsch, P. R., Ward, E., Devonshire, J., \& Hidalgo-Díaz, L. (2013). Pochonia chlamydosporia: Advances and Challenges to Improve Its Performance as a Biological Control Agent of Sedentary Endoparasitic Nematodes. Journal of nematology, 45(1), 1-7.

Nautiyal, C. S. (1999). An efficient microbiological growth médium for screening phosphate solubilizing microorganisms. FEMS Microbiology Letters, 170, 265-270.

Nelson, E. B., Simoneau, P., Barret, M., Mitter, B., Compant, S. 2018. Editorial special issue: the soil, the seed, the microbes and the plant. Plant Soil. 422:1-5.

Olivares, B. C. M. \& López, L, V. (2002). Fungal egg-parasites of plant-parasitic nematodes from Spanish soils. Revista Iberoamericana de Micología, 19, 104-110.

Patel, D., Patel, A., Vora, D., Menon, S., Vadakan, S., Acharya, D. \& Goswani D. (2018). A resourceful methodology to profil indolic auxins produced by rhizo-fungi using spectrophotometry and HPTLC. 3 Biotech, 8, 413.

Silva, S. D., Carneiro, R. M. D. G., Faria, M., Souza, D. A., Monnerat, R. G. \& Lopes R. B. (2017). Evaluation of Pochonia chlamydosporia and Purpereocillium lilacinum for suppression of Meloidogyne enterolobii on tomato and banana. Journal of Nematology, 49(1), 77-85.

Sunitha, V. H., Nirmala, D. D. \& Srinivas C. (2013). Extracellular enzymatic activity of endophytic fungal strains isolated from medicinal plants. World Journal of Agricultural Sciences, 9(1), 1-9.
Zavala, G. E. A., Escudero, N., Lopes, M. F., Aranda, M. A., Exposito, A., Ricaño, R. J., Narano, O. M. A., Ramírez, L. M. \& Lopez, L. L. V. (2015). Some isolates of the nematophagous fungus Pochonia chalmydosporia promote root growth and reduce flowering time of tomato. Annals of Applied Biology, 166(3), 1-12. 